Global Conferences Series:

Social Sciences, Education and Humanities (GCSSSEH), Volume 2, 2019

The $2^{\text {nd }}$ International Conference on Sustainable Development \& Multi-Ethnic Society

DOI: https://doi.org/10.32698/GCS.0174

\title{
Values in History Education in ASEAN Countries
}

\author{
Raja Yong Zahariah Raja Badaruddin ${ }^{1}$, Mohd Mahzan Awang ${ }^{2}$, Abdul Razaq \\ Ahmad $^{3}$ \& Asmahani Mukhtar ${ }^{4}$ \\ ${ }^{1}$ SK Kantan Permai, MALAYSIA \\ ${ }^{234}$ Faculty of Education, MALAYSIA \\ E-mail: rajayongzahariah@gmail.com
}

\begin{abstract}
Value is an issue that is often discussed in history education since it helps to mould national identity. History education is seen as the main medium in nurturing patriotism, loyalty and respect the differences among the students. These elements are important for developing countries as every good citizen adds to the strength of a nation. This paper is focus on values concept that applied in history education in Malaysia, Indonesia and Singapore. The issue discussed in this paper is the barriers in implementing values during conducting the learning process in this three countries. Actions that can be taken in ensuring the effectiveness of nurturing values also included in this discussion.
\end{abstract}

Keywords: Values, history education, ASEAN countries, barriers, actions

\section{Introduction}

Education is an important process that every person must follow in order to generate knowledge and to improve their quality of life. Humans need to learn something to enable them to make changes in themselves. This statement is supported by Norazri (2015) who states that through education, humans can achieve higher civilization and live a more systematic life process. Without education, an individual cannot develop selfpotential and positive personality because they do not have opportunity to emulate or learn good things in order to live their lives perfectly. This is because, Ross and Wu (1996) argue that education has a profound effect on the various opportunities of human life to obtain and maintain quality of life.
Abdul Rahim Hamdan and Azharul Nizam Zahari (2009), perceive that education systems and concepts should be concerned with generic development and not just focus on development of physical aspects. From this point of view, it is found that it is important for an educator to incorporate elements of virtues while implementing teaching and learning process $(\mathrm{PdPc})$. In the age of technology boom, producing students of high moral character and identity is one of the main goals of nation's education system. Latifah Abdul Majid, Wan Nasyrudin Wan Abdullah and Nurul Hidayah (2012) define virtues as good treatment, civilization and ethics of human individual in relation to man, nature and God. Mohammad Chowdhury (2016) points out that application of virtues promotes generic development and student character development. Therefore, educators should be wise to use appropriate techniques in efforts to apply these elements so that student self-potential can be developed holistically. 
History is one of the important subjects that can shape value in student especially in relation to citizenship elements. People who love and cherish the country can be shaped as they learn history and practice values they have learned. Nur Syazwani Abdul Talib, Kamarulzaman Abdul Ghani and Nur Azuki Yusuff (2016) argue that admirable personalities can be shaped through History subject as students take lessons from stories of previous personalities. This experience allows them to think about what to do before acting to avoid regret later. History is also seen as key medium in educating people to be loyal and proud citizens of their own homeland. This statement is in line with the views of Zainal Abidin Borhan (2011) who stated that through the history of the nation it is possible to produce great citizen who believes in the origin and civilization as well as maintains identity.

This concept paper will look at application of values in subject implementation in three ASEAN countries - Malaysia, Indonesia and Singapore. According to Mohamed Irwan Mansor (2017) ASEAN or in full Association of South East Asian Nations is a regional organization made up of Southeast Asian nations to keep their common interests. Regional cooperation based on Rajendran's (1985) view can be understood as a unitary inter-nation forming a large organization among neighboring countries. These three countries were chosen because of the uniqueness of their people from diverse ethnic backgrounds and for having similar history of tradition. We can see how these countries use History subject as a bond of racial unity by instilling positive values in students.

Each country has its own goals to achieve through History curriculum implemented. However, average researcher states that one of the main goals of History education in multicultural countries is to form understanding to establish unity. Mohd Samsudin and Shahizan Shaharuddin (2012) pointed out that historical education is important for establishing racial understanding and as means for them to respect history of indigenous peoples while recognizing role of minorities. The nation that values history is said to be nation of high identity. So, what value is applied through implementation of History subject in education system in these three countries? There are obstacles in implementing the PdPc process of this subject effectively in Malaysia, Indonesia and Singapore where solutions can be thought of.

\section{Implementation of History Education}

\subsection{History Education in Malaysia}

Malaysia is a country that focuses on content and implementation of History subject in its educational system. During British invasion, subject of Tawarikh was introduced in 1863 in English-language schools. The content of lesson was more euro-centric because according to Sharipah Aini Jaafar and Arba'iyah Mohd Noor (2016) local history at that time was depicted in negative and uncivilized way as compared to western history of high glory. After achieving independence, the government made changes in the content of History subject to be more localized but in stages due to the lack of material written by local writers.

The content of History subject covers Malaysian History, Asian History and World History, organized according to students' level of education either in primary or secondary school. One of the main goals of this History subject is to create unity, thus Mohd Samsudin and Shaharuddin (2012) argue that in shaping content of this subject at school level, matters involving minority participation should not be overlooked. Looking at content of today's History, many topics are provided to introduce diversity of cultures, practices, customs and races found in Malaysia.

History subjects proved to be important when the government decided to make it a core subject for all 4th graders by in 2014. According to Muhamad Yazid Khalil (2018), this was for understanding as a citizen, appreciation of patriotic spirit and application of civic values to students can be practiced from the beginning. The prestige of History in Malaysia continues to be raised when it becomes a compulsory subject for the Malaysian Certificate of Education (SPM) beginning in 2013. This decision is not intended to burden students but Mohd Mahzan Awang, Abdul Razaq Ahmad and Nur Syazwani Abdul Talib (2016) argue this action is an effort to educate students to be good citizens.

\subsection{History Education in Indonesia}

Indonesia is a country that emphasizes on homeland history because Mursetyadi Yuli Sadono and Muhsinatun Siasah Masruri (2014) argue that History education can help shape character of Indonesian people. Students in primary education will learn selected events that will bring awareness to values and spirit of community in the face of challenges. According to S.Hamid Hassan (2012), selection of events included in lower level curriculum should be close to students, the scope of which extends to national level.

In recent times, Indonesian history education at the secondary level has been divided into two sections, the 
general and the demand groups. The content of the lessons learned in general by students in Indonesia goes from prehistoric era to reformation era. For students involved in the demand group, according to Abrar (2015), they will learn about Indonesian life journeys that involve things like advances in knowledge and information technology.

\subsection{History Education in Singapore}

The content of historical education in Singapore has to do with history of Malaysia in particular before the end of British colonial era. These subjects were initially taught at primary and secondary levels. The titles touched on at lower levels include cultural diversity, background and religion in Singapore as well as Singapore and Malay history in colonial era. In Year 6, students will learn about the challenge of achieving independence. According to Kevin Blackburn and Zonglun Wu (2019) this title will discuss content from the time of Japanese occupation to the time of nation development after Singapore became an independent nation. However, in 1973, Minister of Education Chai Chong Yii stated that beginning in 1975, subject of History, Geography and Civic would be incorporated into Education for Living subject.

At secondary level, students were exposed to titles of ancient civilizations that included Western, Middle East and early Southeast Asian governments until the fall of Malacca Malay Sultanate. They also taught about history of modern world covering topics up to the end of Malaya's history. Kevin Blackcurn and Zonglun Wu (2019) stated that in early 1979, Singaporean politicians had voiced their desire to form a more 'Singapore centric' History curriculum. In 1984, Singapore history curriculum was introduced in secondary schools. This introduction allowed the students to study social and economic history of their country from Raffles era of 1819 to independence in 1965.

According to Djunaidi (2015) the purpose of learning Singapore subjects was to learn history of the formation, to learn about Singapore in 1819, to find identity to shape Singapore's future and early history of Singapore's founding (1965-1975). This is done to enable their people to know the country's origin and to foster spirit of love for the country.

\section{Applying Values in Historical Education in Malaysia, Indonesia and Singapore}

\subsection{The value of Patriotism in Historical Education}

History Education is a medium for a government to deliver, expose and educate its citizens about origins and important stories of the rise of homeland. This statement is corresponding with views of Mohd Samsudin and Shahizan Shaharuddin (2012), who state that History education can educate young people about the past crusade to make their country a successful nation. The awareness been trying to convey shows that through History subject the patriotism value can be instilled in students.

Ruhanie (2005) defines patriotism as a manifestation or willingnss practice to defend and sacrifice for the country. The stories presented in History curriculum if taught with enthusiasm will open the eyes of students to realize how important for them to love and appreciate freedom they have. Aminudin Mansor (2018) also argues that people who willing to defend country sovereignty under any circumstances are foundation of patriotic spirit that results from process of learning History.

Malaysia, Indonesia and Singapore have provided contents of History curriculum that emphasizes local history content so that students can know and understand better the origins of homeland. Aminudin Mansor (2015) argues that learning History enables us to understand early history of civilization which results in high sense of identity. When reviewing textbook content used in Malaysia, every topic is organized thematically about world history, Asia and of course history of the country. The title of National Independence Crusade and Local Leadership Crusade taught for Year 5 at primary level shows how serious the government wants to create awareness from early childhood on importance of appreciating prosperity achieved. According to Mohd Shamsudin and Shahizan Shaharuddin (2012), the title of National and Nation Building to the Origins of Sovereign Malaysia taught in Form 5 can create elements of patriotism such as pride in nation's heritage and nation among students.

The contents of Indonesian History curriculum also emphasize value of patriotism in students such as topics that touch on the birth of Pancasila and Development of Indonesian society in prehistoric times. The story of local opposition to Dutch occupation and change of administrative system in Indonesia can certainly have the effect of injecting spirit of patriotism into maintaining independence. Abrar (2015), also stated that one of the aims of Indonesian History curriculum is 
to enhance nationality, love for homeland and appreciate service of people of Indonesia. The Indonesian History Curriculum, which embraces the title of Indonesian heroism and nationalism, is certainly able to rekindle love for the country among its people.

Shuyi Chua and Jasmine B.Y. Sim (2014) states that Singapore's government fosters patriotism through education with ultimate goal of achieving social cohesion and national development. History education curriculum at secondary level, according to Djunaidi (2015) students will be exposed to the title of Early Decade of Singapore Nation Emergence which touches on changing lives of Singaporeans after independence. Students will be educated on their nation's ability to develop even though Singapore is a small country. This realization can instill patriotism value in students thus strengthens their identity.

\subsection{Values of Respect in a Multicultural Society}

Furnivall (1939) defined plural society as a society that emerged as result of colonial policies in which population emigrated according to requirements of its economic system. In the context of Malay World, Nazri Muslim et.al (2016) states that plural society was formed before the advent of Western colonists. The existence of multiracial societies in Malaysia, Indonesia and Singapore is a uniqueness that symbolizes prosperity and pride of these countries. This is because, despite their different backgrounds, they are still able to coexist and develop the country. Nonetheless, unity that is built in this society must be maintained through practice of values such as respect in order to avoid misunderstandings.

Abd Aziz, Farrah Wahida, Aimi Khairunnisa and Nurliana (2017) state that if diversity is to be cause of conflict and strife, dream of peace is seen as difficult to achieve if every ethnic group is ethnocentric. Therefore, it is important for these countries to form a united people and application of respect value through History subject is an appropriate initiative. The Curriculum and Assessment Standard Document (DOSH) of History in Malaysia contains value of respecting religious and cultural diversity as one of the elements of citizenship as well as civic values that must be applied when implementing PdPc. The title Our People of Malaysia in the Year 6 History textbook, for example, has given students an insight into religious practices, culture and traditional elements found in various societies in Malaysia. Based on that content, students will be educated on diversity of community thus help to improve their understanding.

Indonesia is also a country with a multiracial society. Mursetyadi Yuli Sadono and Muhsinatun Siasah Masruri (2014) pointed out that Indonesia as a multicultural country needs an education system that values multicultural spirit and values. History is seen as conduit for fostering mutual understanding and mutual respect among Indonesian students. According to Laili Masithoh, Sutrisno Mohamad and Mursalat Kulap (2017) history will reveal the development of multicultural systems, legislation, languages, family systems, beliefs and so on to those who study them. In context of Indonesian history education, topics related to early civilization of world community and Indonesia were able to educate students on the process of the formation of various societies. The process of learning can enhance understanding of others and respect differences.

Singapore has included title relating to State of Singapore during 1819 in History curriculum which discusses conditions of people who came to Singapore and their backgrounds. This title allows students to get to know different cultures and practices of society. Applying respectful values when educating students can help students understand a community.

\section{Challenges of Applying Values in the History of Student Learning}

Sukarno once said "Never forget history" because a strong nation is a nation that values struggle of people in the past. Based on these words, it shows that History is an important subject for implementation in a national education system. Sharipah Aini Jaafar and Arba'iyah Mohd Noor (2016) stated that history is a very important tool in nation's efforts to instill and nurture values and thinking of younger generation towards people and nation, especially in terms of unity. However, it is not easy to ensure that values contained in History lesson can be applied effectively because there are several factors that make it difficult to do so.

History is often considered a boring subject because it only deals with things that have happened and involves many confusing timelines. The sheer content of lessons and failure of pupils to relate one story to another make them bored. This statement is in line with the views of Anuar Ahmad, Siti Haishah Abdul Rahman and Nur Atiqah T. Abdullah (2009) who state that History subject has little place in students' hearts as it is boring and dense with facts. The boredom of students will make it 
difficult to focus on content of lessons thus make it difficult for teachers to incorporate PdPc values. Manisah Mohd. Ali and Norizza Sahal (2016) also argue that if students are not able to focus on what is being taught during the PdPc process, then their potential for misunderstanding content is enormous. Such situation would hinder process of effectively applying value of virtues.

Teachers are key individuals who play important role in delivering the content. If teachers are unfamiliar with content of curriculum and use less creativity in conducting classroom, students will find it difficult to understand what is being said. This situation is further worsened when some schools think that History lesson can be taught by anyone. T. Marimuthu (1984) states that this action may result in some information being passed down to students because these teachers lack control over content. Teacher's reliance on textbooks alone also reduced effectiveness of PdPc process. This is because, Sharipah Aini Jaafar and Arba'iyah Mohd Noor (2016) argue that excessive use of textbooks will make History PdPc process less stereotypical, less creative and imaginative. These challenges need to be overcome for $\mathrm{PdPc}$ process to be implemented effectively and to enable application of virtues values to self.

\section{Steps to Improve the Effectiveness of the Value Applying Process in History Subjects}

The age-old demands of great change in education system of the world to ensure that content and methods of teaching are relevant to the needs of students. In implementing History PdPc, teachers need to diversify their teaching techniques so that students are more active and interested in hearing content of the lessons to be delivered. Ramkrishnan, Renuka, Norizan Esa and Siti Hawa Abdullah (2013) stated that usage of multimedia will give students opportunity to actively participate in learning History. The application of video, for example, allows students to see clearly story that the teacher is telling and makes it easier for them to understand and learn from the story. The use of technology can also encourage students to become self-reliant in their studies because they can find their own information about history without having to rely on teachers. Furthermore, Nursyazwani Abdul Talib et.al (2016) stated that usage of technology today enables students to access information quickly. This enables virtues values to be nurtured not only through content of curriculum in History but through the process of pupils seeking information. They need to be self-reliant, honest and helpful with each other as they search for content; they evaluate the information obtained from the internet, whether right or wrong.

Teacher's competence level also needs to be improved to ensure that History Pdpc process runs smoothly. According to M.Kaviza, Fauziah Abdul Rahim and Nurliyana Bukhari (2018), history teachers need to have extensive knowledge and skills in implementing History teaching and learning methods using historical sources. Based on this statement, it is understood that History teachers need to constantly update their pedagogical knowledge and knowledge of history so that they are better prepared to handle the classroom. Johansson (2017), argues that inadequate knowledge base of teachers, knowledge and skills are an impediment to effective PdPc implementation. Therefore, to address this problem History teacher need to take appropriate courses or workshops to further improve quality of their teaching. Positive and thoughtful teachers who incorporate teaching methods have potential to attract students to participate in classroom learning.

In short, usage of technology and teachers' skills enhancement in implementing History subjects can improve the effectiveness of the process of applying value to students. History needs to be taught and studied so that the lessons and stories contained in this subject can be replicated by students.

\section{Conclusion}

Malaysia, Indonesia and Singapore are three ASEAN countries with strong historical ties. The three countries regard History as an important subject in shaping national identity. The diversity that exists is a uniqueness of these countries but requires effort to strengthen existing unity. The implementation of History curriculum is seen as an appropriate step because values can be implemented within student during PdPc process.

The value of patriotism and respect for differences are among the key values that must be applied in implementing History PdPc. People who love their homeland and is united can be shaped if students really understand content of lesson. Therefore, teachers need to conduct classes creatively such as using technology application so that students do not get bored and want to hear what is lesson about to convey.

\section{References}

[1] Abd Aziz A'zmi, Farrah Wahida Mustafar, Aimi Khairunnisa Abdul Karim \& Nurliana Suhaini .2017. 
Realiti Kepelbagaian Kaum ke Arah Perpaduan Nasional Pasca Merdeka. Jurnal Sains Sosial , 1-24.

[2] Abrar. 2015. Kurikulum Sejarah Jenjang SMA : Sebuah Perbandingan Indonesia- Australia. Jurnal Pendidikan Sejarah, 4(1),14-31.

[3] Anuar Ahmad, Siti Haishah Abdul Rahman dan Nur Atiqah T. Abdullah. .2009. Tahap Keupayaan Pengajaran Guru Sejarah dan Hubungannya dengan Pencapaian Murid di Sekolah Berprestasi Rendah. Jurnal Pendidikan Malaysia , 34(1),53-66.

[4] Blackburn, K., \& Wu, Z. L. 2019. Decolonizing the history curriculum in Malaysia and Singapore.

[5] Chowdhury, M. 2018. Emphasizing morals, values, ethics, and character education in science education and science teaching. MOJES: Malaysian Online Journal of Educational Sciences, 4(2), 1-16.

[6] Chua, S., \& Sim, J. B. Y. 2014. Crossing boundaries: An exploration of how three Social Studies teachers understand and teach patriotism in Singapore. Citizenship Teaching \& Learning, 10(1), 79-93.

[7] Djunaidi. 2015. Sistem Pendidikan dan Pendidikan Sejarah di Singapura Sebagai Refleksi bagi Pengembangan Kurikulum di Indonesia. Jurnal Pendidikan Sejarah, 4(1), 32-41.

[8] J.S Furnivall. 1939. Netherlands India : a study of Plural Economy. Cambridge: University Press.

[9] Johansson, P. 2017. Learning study as a clinical research practice to generate knowledge about the learning of historical primary source analysis. Educational Action Research, 25(1), 167-181.

[10] Laili Masithoh Hamdiyah, Sutrisno Mohamad \& Mursalat Kulap. 2017. The History Education and Establishment of Multicultural Awareness of Students. International Journal of Multicultural and Multireligous Understanding , 36-41.

[11] Latifah Abdul Majid, Wan Nasyrudin Wan Abdullah \& Nurul Hifdayah Ahmad Zakhi. 2012. Integrating Noble Values and Identity Formation into Kindergarten Children through the Use of Multimedia. Jurnal Hadhari Special Edition, 51-65.

[12] M.Kaviza, Fauziah Abdul Rahim \& Nurliyana Bukhari. 2018. Tahap Kesediaan Guru-guru Sejarah dalam Melaksanakan Kaedah Pengajaran dan Pembelajaran Berasaskan Sumber Sejarah: Satu Tinjauan di Negeri Perlis. Juku: Jurnal Kurikulum dan Pengajaran Asia Pasifik, 6 (2),23-31.

[13] Manisah Mohd Ali \& Norizza Sahal. 2016. Intervensi Meningkatkan Tumpuan dalam Pembelajaran Murid Bermasalah Pembelajaran. Jurnal Pendidikan Malaysia, 41(1),1-6.

[14] Marimuthu,T. 1984. 'Policies For Multicultural Education In Malaysia'.Paper Presented at the
4thNational Convention on Education. Malaysian Association for Education. Kuala Lumpur. 68thAugust 1984

[15] Mohamed Irwan Mansor. 2017. ASEAN as a regional organization . Journal of Social Sciences and Humanities , 1-13.

[16] Mohd Mahzan Awang, Abdul Razaq Ahmad, Nur Syazwani Abdul Talib. 2016. Penggunaan Multimedia dalam Pendidikan Sejarah pada Abad ke21 dan Hubungannya dengan Minat Belajar Sejarah. Jurnal Pemikir Pendidikan, 44-56.

[17] Mohd Samdsudin \& Shahizan Shaharuddin. 2012. Pendidikan dan Pengajaran Mata Pelajaran di Sekolah di Malaysia. Jebat : Malaysian Journal of History, Politics and \& Strategy, 116-141.

[18] Muhamad Yazid Khalil. 2018. Tahap Pengetahuan Guru Sejarah Sekolah Rendah Dalam Kemahiran Pemikiran Sejarah. Prosiding National Innovation and Invention Competition through Exhibition, 1-12

[19] Nazri Muslim, Fazilah Idris, Rozita Ibrahim, Rozmel Abdul Latiff, Nsruddin Yunos, Ahmad Zamri Mansor \& Hasanah Abd. Khafidz. 2016. Persepsi Pelajar UKM Terhadap Perhubungan Etnik di Malaysia. AlHikmah, 8(2),38-59.

[20] Norazri Mohd Zaidin. 2015. Penerapan nilai-nilai murni dalam proses pengajaran dan pembelajaran ke arah pembentukan sahsiah pelajar di Kolej Kemahiran Tinggi Mara (Masters dissertation). Universiti Tun Hussein Onn.

[21] Nur Syazawani Abdul Talib, Kamarulzaman Abdul Ghani \& Nur Azuki Yusuff. 2016. Tahap Pengetahuan dan Sikap Graduan IPT serta Hubungannya dengan Minat Terhadap Sejarah : Usaha Awal Memupuk Semangat Cinta Negara . Jurnal Pemikir Pendidikan, 57-72.

[22] Nur Syazwani Abdul Talib, Kamrulzaman Abdul Ghani, Nur Azuki Yusoff \& Mohd Mahzan Awang .2016. Kaedah Pembelajaran Sejarah dengan Mengambil Kira Minat dan Peningkatan Prestasi.

[23] Rajendran,M. 1985. Asean's Foreign Relations. Kuala Lumpur: Arena Buku.

[24] Ruhanie Haji Ahmad. 2005. Patriotisme Malaysia Penangkis Neoimprealisme. Kuala Lumpur: Utusan Publications \& Distributors SDN BHD.

[25] Sadono, M. Y., \& Masruri, M. S. 2014. Keefektifan VCT dalam pembelajaran sejarah untuk meningkatkan nilai nasionalisme, demokrasi, dan multikultural. Harmoni Sosial: Jurnal Pendidikan IPS, 1(1).

[26] Sharpah Aini Jaafar \& Arba'iyah Mohd Noor. 2016. Pelaksanaan Pengajaran dan Pembelajaran Sejarah di Sekolah- Sekolah di Malaysia, 1957-1989. Sejarah, 40-57. 
[27] Wu, K. B. 2019. Decolonizing the history curriculum in Malaysia and Singapore. London: Routledge, Taylor \& Francis Group. 